\title{
Philosophy According \\ to Tacitus:

Francis Bacon and the
Inquiry into the Limits
of Human Self-Delusion

Guido Giglioni

The Warburg Institute

\begin{abstract}
Bacon belonged to a cultural milieu that, between the sixteenth and the seventeenth centuries, proved to be especially receptive to influences coming from such continental authors as Machiavelli, Bodin, Duplessis-Mornay, Hotman, and, through Lipsius, a particular brand of Stoicism tinged with Tacitean motifs. Within the broader question of Tacitus' influence on Tudor and Stuart culture, this article focuses on the issue of how Bacon's characteristic insistence on the powers of the imagination (fingere) and of belief (credere) in shaping human history may have influenced his view that human beings suffer from an innate tendency to self-delusion.
\end{abstract}

\section{Tacitean Stoicism and Stoic Tacitism}

During the Renaissance, Tacitus' works were interpreted and applied in a wide variety of ways. Tacitus became a source of inspiration for thinking about revolutions, wars, conspiracies, subtle transitions from freedom to despotism (and vice versa), prudent action in the administration of the State, cautious behavior at court, the exercise of political wisdom, and legal expertise in Roman law. The model of Tacitean history could be used to foster republican liberty (Niccolò Machiavelli), to promote political realism (Giovanni Botero), to preserve a sphere of intellectual freedom in situations dominated by tyrannical rule (Justus Lipsius), and to claim a divine origin for monarchical regimes (King James I). He could show people how to live safely under tyranny and tyrants and how to secure their power in situations of political instability (Francesco Guicciardini). Huguenot political thinkers developed theories about the right to resist monarchical power by relying on interpretations of Tacitus which were in-

I would like to thank Jill Kraye and James A. T. Lancaster for their comments on an earlier version of this article and for improving its English.

Perspectives on Science 2012, vol. 20, no. 2

(C) 2012 by The Massachusetts Institute of Technology 
fused with elements of Machiavelli's idealism. Tacitus could even be seen (for instance, by Michel de Montaigne) as a repository of examples concerning Stoic fortitude, particularly with regard to illustrious suicides. As Kenneth C. Schellhase has aptly noted, Machiavelli read Tacitus "to resist," Andrea Alciato "to resign" (Schellhase 1976, p. 93). ${ }^{1}$

Unlike many other classical authors, Tacitus was poorly known during the Middle Ages and the early Renaissance. His works began to be disseminated in Europe from the 1470s onwards, after Vindelin de Spira and Puteolanus' editions of 1472-3 and 1476-7. It was only after 1515, however, that he became part of the great canon of classical historians established by Renaissance humanists. In that year, Filippo Beroaldo the Younger published his edition of Tacitus, followed, in 1517, by Andrea Alciato's Annotationes in Cornelium Tacitum, and then by Beatus Rhenanus' two editions of Tacitus in 1533 and 1544 (Martin 2009).

It goes without saying that, in the history of European Tacitism, Justus Lipsius (1547-1606) was a pivotal figure. ${ }^{2}$ Between 1574 and 1607, he produced authoritative and influential editions of Tacitus and Seneca, which set the tone for subsequent interpretations of both authors. Above all, Lipsius' editions contributed to the popularization of a characteristically Senecan and Tacitean view of Stoicism (especially evident in his De constantia, published in 1583 and translated into English by John Stradling in 1595). ${ }^{3}$ Lipsius called Tacitus "the father of prudence" (pater prudentiae) and Seneca "the source of wisdom" (fons sapientiae) (Lipsius 1675, $2: 315) .{ }^{4}$ He saw in Seneca a model of theoretical analysis, in Tacitus a reservoir of examples relating to Stoic magnanimity-Stoicism in action, so to speak. Other works by Lipsius, such as the Manuductio ad Stoicam philosophiam and Physiologia Stoicorum (both published in 1604), represented the most comprehensive and systematic attempt at the time to recover the original Greek sources of Stoic philosophy. In this instance, too, Lipsius left his characteristic mark on the whole operation, purging the views of Zeno, Cleanthes, and Chrysippus of all traces of monistic materialism, while coloring selected excerpts of Greek Stoicism with elements of

1. On Tacitus' influence on Renaissance European culture, see Ramorino 1898; Toffanin 1921; Tenney 1941; Momigliano 1947; Ruysschaert 1949; Brink 1951; Williamson 1951; Burke 1969; Miner 1970; Schellhase 1976; La Penna 1976; Whitfield 1976; Salmon 1980; Salmon 1989; Burke 1991; Mellor 1993, pp. 137-62; Gajda 2009.

2. On the significance of Lipsius' work, see Nordman 1932; Zanta 1914, pp. 151-240; Dal Pra 1946; Saunders 1955; Abel 1978, pp. 67-113; Isnardi Parente 1986; Grafton 1987; Morford 1991; Lagrée 1994; Lagrée 1996; Lagrée 1999; Lagrée 2010; Joly 1996; Paganini 2000; Long 2003, pp. 379-82; Kraye 2004; Papy 2004; Carabin 2004, pp. 83959; Leira 2007; Leira 2008.

3. See Papy 2008; Giglioni 2011b.

4. On Tacitean prudentia in Lipsius, see Morford 1993. 
patristic and Neoplatonic wisdom. We might call Lipsius' philosophical project a form of "Tacitean Stoicism" or "Stoic Tacitism," using this label to indicate a particular version of Stoic philosophy marked by a flexible view of virtue, suitable both to a life of political commitment and a more severe form of ethical conduct, and driven by ideals of freedom, endurance, and disinterested generosity.

During the two years he spent in Rome as secretary to Antoine Perrenot, Bishop of Granvelle (between 1567 and 1569), Lipsius came into contact with a number of Tacitean scholars. Among these, MarcAntoine Muret (1526-1585), the renowned editor and translator of Greek and Roman authors, was probably the scholar who convinced Lipsius, upon their meeting in Rome in 1567, to work on Tacitus. In any case, the way Lipsius describes his encounter with the Roman historian in his Politica (published in 1589) confirms the myth of a seductive and persuasive Tacitus, who instills dangerous ideas into the minds of his readers. Tacitus, wrote Lipsius, did not enter his mind by force but instead offered himself without being summoned (offerebat se non vocatus) (Lipsius 2004, p. 254). In the preface to his 1574 edition of Tacitus, he emphasized that other historians had not always provided the same amount of ethical and political instruction: "I have always felt more invigorated from reading Livy, but not always better, nor more prepared for all the contingencies of life" ("Dedicatory Letter to Emperor Maximilian II," in Tacitus 1574, p. 4). With his inaugural lecture at the University of Jena, Lipsius gave, in Schellhase's words, "one of the most dynamic applications of Tacitus to politics in the Renaissance" (Schellhase 1976, p. 118). ${ }^{5}$ In his 1589 edition of Tacitus' works, Lipsius described him as a "marvellous" writer, whose work "is not only a history, but a garden and seminary of precepts" (quoted in Tenney 1941, p. 153). For these reasons, he felt entitled in the Politica to address him in such familiar terms as meus scriptor and ille noster (Lipsius 2004, pp. 296, 316, 430, 560).

It was mainly through Lipsius that currents of Tacitism and Stoicism reached England at the turn of the seventeenth century. ${ }^{6}$ His influence is evident in editors and translators such as Henry Savile (1549-1622), who translated Tacitus' Agricola and the first four books of Historiae in 1591; Richard Greneway (fl. 1598), who translated the Germania and Annales in 1598; and Thomas Lodge (c. 1558-1625), whose Workes of Lucius Annaeus Seneca, both Moral and Naturall was published in 1614. The influence of Lipsius, as I shall try to demonstrate in this essay, is also apparent in the

5. See also Tuck 1993, pp. 45-64.

6. On the spread of Stoic ideas in England, see Smith 1948; Salmon 1980; Salmon 1989; Womersley 1991; Womersley 1992; Tuck 1993, 31-64; Ferraro Parmelee 1994. 
writings of Francis Bacon, especially in the manner in which he tempered the speculative abstractions of Stoicism with a sense of Tacitean realism. Most of all, Tacitus provided Bacon with a model of historical and psychological analysis, by means of which he was able to explore the complex interplay of both imaginary and genuine reality in shaping human experience.

Bacon admired Tacitus. Writing to Fulke Greville, he declared: "Of all histories I think Tacitus simply the best" (Bacon 1996, p. 105). ${ }^{7}$ As he made clear in his Temporis partus masculus, written around 1602, he assigned a clear philosophical value to the way Tacitus had carried out his historical investigations. In his opinion, the Roman historian had dealt with ethical questions better than even the most distinguished philosophers: "Most people admire Aristotle and Plato, but Tacitus is full of fresher observations about human behavior" (SEH III, p. 538). ${ }^{8}$ In fact, when reading the Essayes one has the distinct impression that Bacon, while toying with Stoic ideas, preferred to turn to Tacitus' prudential realism, attracted to his political view of both nature and human affairs. Take, for instance, the beginning of his essay "Of Adversitie":

It was an high speech of Seneca, (after the manner of the Stoickes) That the good things, which belong to Prosperity, are to be wished; but the good things, that belong to Adversity, are to be admired. Bona Rerum Secundarum, Optabilia; Adversarum, Mirabilia. Certainly if Miracles, be the Command over Nature, they appeare most in Adversity. It is yet a higher speech of his, then the other, (much too high for a Heathen) It is true greatnesse, to have in one, the Frailty of a Man, and the Security of a God. Vere magnum, habere Fragilitatem Hominis, Securitatem Dei. This would have done better in Poesy; where Transcendences are more allowed. (OFB XV, p. 18$)^{9}$

For Bacon, philosophy "after the manner of the Stoickes" was closer to "poesy" (i.e., the ability to recreate fictional worlds from the potentialities of the human imagination) than to a sustained and critical attempt to understand reality. To believe that humans could reach a state of divine perfection in this life through the exercise of virtue was a sign of both arrogance and delusion. Ideals that cannot be fulfilled in real life-

7. Bacon also refers to Tacitus in the context of an important discussion concerning history in the Advancement of Learning (OFB IV, p. 69).

8. See Croll 1966, p. 192; Schellhase 1976, p. 230, n. 35. On Bacon's Temporis partus masculus, see Deleule 2009, pp. 5-45.

9. See Seneca, Ep. LXVI, 29; LIII, 12. These passages are also discussed in De sapientia veterum (SEH VI, p. 675). 
"transcendences"-belonged solely to the realm of poetic imagination rather than philosophy.

Within the movement of late-Renaissance Stoicism, the tension between Tacitean and Senecan interpretations can, by and large, be viewed as reflecting a far-reaching contrast between political reality and natural reason. Bacon had a penchant for Lipsius' Politica (1589), a work full of Tacitean and Machiavellian motifs (Bacon 1996, p. 102). ${ }^{10}$ In the essay "Of Empire," he remarked how "the wisdome of all these latter Times in Princes Affaires" depended upon quick instruction in emergency situations ("fine Deliveries and Shiftings of Dangers and Mischiefes when they are neare") rather than on carefully planned political actions ("solid and grounded Courses to keepe them aloofe"). He rounded out his argument with what he thought was a quotation from Tacitus ("Sunt plerumque regum voluntates vehementes, et inter se contrariae"), but which, in reality, came from Sallust's Bellum Jugurthinum, CXIII, 1 (OFB XV, p. 60). This lapsus calami does not change the sense of what Bacon intended to say: a situation of fragmented and factional power was, against the background of centralizing monarchical regimes, more in need of timely and circumstantial interventions than of a planned and principled course of action. Bacon characterized this specific situation with the poignant phrase "Soloecisme of Power," by which he meant "to thinke to Command the End, and yet not to endure the Mean" (OFB XV, p. 60). This emphasis on the political question of the means available in each individual situation recalls Machiavelli, of course; but it is also a way of referring to such classical authorities in the field of history and political theory as Sallust and Tacitus.

Schellhase has noted that the seventeenth century, a time during which the political uses of Tacitus were waning throughout the rest of Europe, was also the time during which his works were lending themselves to new political interpretations in England (Schellhase 1976, p. 157-66). J. H. M. Salmon has pointed out that Tacitus influenced the English scene through Lipsius' Stoicism, pervaded as it was by elements of Senecan piety, Neoplatonic asceticism, and ideas from the Church Fathers; Salmon argues that, despite Lipsius' mediation, a number of English writers soon adopted a darker view of Tacitus (Salmon 1989). By contrast, David Womersley sees in Tacitus one of the channels through which the Huguenot and Machiavellian glorification of anti-tyrannical virtues was smuggled into England. In this, he views himself as closer to the interpretation of Gerhard Oestreich, according to whom strands of continental Stoicism provided ideological support for contemporary notions of monarchical

10. On Lipsius' Politica see Senellart 1999. 
statecraft, military discipline, and scholarly gravitas (Oestreich 1982; Womersley 1991; Womersley 1992).

Before English writers and politicians began to engage with Tacitus, the models of historical and political inquiry were Polybius, Plutarch, and Livy. Tacitus became fashionable during the late Tudor and Stuart period, when his ideas seeped into both Catholic and Protestant circles. Even King James' Basilikon Doron (1599) is studded with numerous references to Tacitus. Yet, it was Sir Philip Sidney and his acolytes, all concerned with promoting a distinctively Protestant form of Tacitean Stoicism, who had started the vogue for Tacitus among English historians, political writers, and courtiers. Sidney was a friend of Philippe Duplessis-Mornay (the right-hand man of Henri de Navarre), who had corresponded with Lipsius, and to whom his De recta pronunciatione (1586) had subsequently been dedicated. Fulke Greville, Charles Blount, Baron Mountjoy, and John Stradling, the translator of Lipsius' De constantia, all gravitated around Sidney. Even after his death, Sidney's sister, Mary Herbert, Countess of Pembroke, continued the tradition, giving patronage to writers interested in continental Stoicism. She herself translated Duplessis-Mornay's Discours de la vie et de la mort (1576), which contained a French version of Seneca's De providentia. Moreover, when Sidney died in the Netherlands, the center of Tacitean interest crystallized around Robert Devereux, Earl of Essex. As David Norbrook has pointed out, "the restless members of the Sidney and Essex circles" were quite active in spreading interest in Machiavelli and Tacitus (Norbrook 2002, p. 153). In all these cases, Tacitus offered a paradigm of ethical and political realism at a time when the space allotted for the exercise of free-thinking was being severely curtailed by the rapid expansion of political absolutism, and while philosophers were experiencing the urgent need to acquire more reliable instruments in order to discern the reality behind the appearances of the worlds-natural and social-that they inhabited. This is also true of Bacon, for whom Tacitus, more than Seneca, was the philosopher who provided instruction on how to maintain the right balance between reality and representation.

\section{Fingunt simul creduntque}

By insisting on the pervasive influence of imagination (fingere) and belief (credere) in human life, Tacitus had demonstrated that the power of appearances manifested itself among human beings in a wide range of dispositions-both to deceive and to be deceived. In his view of human history, beliefs were seen as constantly feeding on themselves so as to produce more or less imaginary, and thus unsubstantiated accounts of reality and, further, to reinforce their false status as real visions of the world. In 
many respects, his work provides a comprehensive phenomenology of human credulity: one has only to think of the many meanings of fama that can be found in the Historiae and Annales (for example, the talk of the multitude, public opinion in general, good or bad reputation, renown).

Tacitus' twin notions of fingere and credere laid bare a view of human experience in which the force of representations and idola could never be erased once and for all. In his account of history, images of the reality of both other people's selves and one's own soul often serve as a device for self-promotion and the maintenance of power. In particular, Tacitus offers an interpretative model of human action based on the observation that human beings tend to produce appearances which they are, in turn, inclined to believe (as signified by the recurring phrase fingunt creduntque). To put it simply, Tacitus' historical actors, largely on account of their inability to control their passions, seem to live in make-believe worlds of their own devising. Reality checks are rare and, even when possible, are difficult to assess. ${ }^{1}$

In the markedly Tacitean essay "Of Empire," Bacon summed up this key point with respect to rulers by stating that " $[\mathrm{t}]$ he difficulties in Princes Businesse, are many and great; But the greatest difficulty, is often in their owne Minde" (OFB XV, p. 60). In his Politica, Lipsius had already observed that, while auctoritas and benivolentia emanate from the person of the king, their actual dwelling place resides in the minds of the people (domicilium in animis populi babet) (Lipsius 2004, pp. 418-19). In a deeply Tacitean spirit, therefore, both Lipsius and Bacon recognized the central role played by "representations" in political life, regardless of whether such representations concerned the mind of the ruler or that of his subjects. In a situation such as this, wherein reality seems to result from entangled clusters of perceptions, appearances, and beliefs, the risk of delusion and selfdelusion looms large. A Stoic intervention, in the Epictetan and Senecan guise, could certainly offer a possible remedy, by taking control of the very organ of representations, namely, the faculty of the imagination. It seems, however, that Bacon and his English contemporaries preferred instead to turn to history as related by Tacitus. Here they could find a model of merciless introspection, capable of alerting the reader to the insidious role played by language, writing, and the shifting representations of mankind's inner worlds.

11. For a classic locus referred to by Bacon, see Tacitus, Annales, VI, 5: "per dolumque comitantibus adliciebantur ignari fama nominis et promptis Graecorum animis ad nova et mira. Quippe elapsum custodiae pergere ad paternos exercitus, Aegyptum aut Suriam invasurum, fingebant simul credebantque." On Tacitus' "history of make-believe," see Haynes 2003; Sailor 2008. 


\section{Bacon on fingere and credere}

In the Advancement of Learning, Bacon pointed to the important role played in human culture by what he called the great "affinitie" between "fiction and beleefe" (OFB IV, p. 26). Here he famously identified the three principal illnesses of learning, what he called its "distempers": vain affectations ("delicate learning"), that is, "when men studie words, and not matter"; vain altercations ("contentious learning"), that is, when sound knowledge degenerates into "vermiculate questions"; and finally, vain imaginations ("fantastical learning"), which Bacon considered to be "the fowlest," in that it "doth destroy the essentiall fourme of knowledge." He assumed that there was an original correspondence between knowledge and reality, between the world of human representations (globus intellectus) and the material world of actual events (globus materiae). ${ }^{12}$ Although the mirroring of the two worlds had become increasingly less reliable after the Fall, Bacon was convinced that, for all its difficulties, a truthful account of things was still possible, owing to the ontological foundation of the original correspondence. As he explained in the Advancement of Learning, knowledge

is nothing but a representation of truth; for the truth of being, and the truth of knowing are one, differing no more than the direct

beame, and the beame reflected. (OFB IV, pp. 25-26)

So far so ontologically predictable: the mirroring of "the truth of being" by the "truth of knowledge" is, in the end, classic Aristotle. Things become more complicated - and more Tacitean, one might add-when Bacon proceeds to explore situations in which representations are disassociated from reality, however. This disassociation can assume two principal forms: "delight in deceiving" (or "imposture") and "aptnesse to be deceived" (or "credulitie"). Bacon described these two forms less as two distinct dispositions originating from two separate roots (namely, "cunning" and "semplicitie"), and more as two expressions of a deeper tendency toward self-deception; a single disposition to adulterate the representations of things and to believe in the fictitious world resulting from them. Tendencies to deceive and dispositions to be deceived fuel each other and create vicious circles of delusion and self-delusion. In this sense, "fame," understood as the common talk of people, represents the paradigmatic instance of Bacon's "fantastical" distemper of learning:

12. Bacon SEH I, p. 772: "legitimae inquisitionis vera norma est, ut nihil inveniatur in globo materiae, quod non habeat parallelum in globo crystallino sive intellectu." On Bacon's parallelism between globus materiae and globus intellectus, see Giglioni 2011a, pp. 14-7. On early modern views concerning the decay of human cognitive powers as a result of the Fall, see Harrison 2007. 
An inquisitiue man is a pratler: so vpon the like reason, a credulous man is a deceiuer: as we see it in fame, that hee that will easily beleeue rumors, will as easily augment rumors, and adde somewhat to them of his owne, which Tacitus wisely noteth, when he sayth: Fingunt simul creduntque; so great an affinitie hath fiction and beleefe. (OFB IV, p. 26. See Tacitus, Annales, VI, 5)

As is clear from this passage, Bacon identified credulous people with deceivers (no matter if the latter were, for the most part, unintentionally so). The reason is that human credulity contributes to the collective adulteration of truth. Bacon shared with Lipsius the same Tacitean view of fama as an inexhaustible source of imagined and fabricated accounts. Credulous people are accomplices in the widespread destruction of "the essentiall fourme of knowledge," which, as we have just seen, Bacon thought was caused by widespread manifestations of "fantastical learning."

In Lipsius' Politica - a book that Bacon recommended in his letter of advice to Fulke Greville "on his studies" (Bacon 1996, p. 102)—one could find a lucid account of these various kinds of imaginary reality and their political uses. Lipsius pointed out that a significant part of a ruler's success in gaining the people's favor depended on his ability to capture the popular imagination through his creation of a sense of awe around his persona; by his manipulation of fama and opinio; by his exploitation of the power of habits and customs (mores); and, finally, by his promotion of public entertainments and ceremonies. He recommended that the prince should expose himself "without restraint" (effuse) to the popular wind (popularis aura) and, quoting Tacitus, to "every murmur of the lowest orders in the theatre" (Lipsius 2004, p. 500; Tacitus 1925, p. 307). Most of all, Lipsius developed the influential view that political prudentia allowed for a certain level of deception (fraudes), calling it "mixed prudence" (Lipsius 2004, p. 506). ${ }^{13}$ Discussing the extent to which one is allowed to deceive other people, Lipsius distinguished between three degrees of deception-levis, media, and magna — and thought that a certain amount of "light" deception was acceptable, provided it fell within the domain of a ruler's prudentia. He defined this form of prudential deceit as "clever planning which departs from virtue or the laws, in the interest of the king and the kingdom" (Lipsius 2004, p. 513). Distrust (diffidentia) and dissembling (dissimulatio), too, could be included as kinds of light deception. Of all Lipsius' suggestions, though, the claim that the prince always be alert (intentus) and live in a state of suspense (suspensus), was the most significant. Quoting Seneca, he added that a prince who is in control of the 
situation should believe only in things that he can clearly see happening before his eyes. This was a crucial point of consideration for any ruler who fancied retaining his power. While in Lipsius' opinion the prince should employ every kind of ruse and tactic to induce belief in people, he also needed to be completely aware of the various mechanisms of make-believe that were in place within his community, and to give his assent only to things that could be checked and verified, preferably with the help of his own senses (Lipsius 2004, p. 512; Seneca, De ira, IV, xxiv, 2).

For both Lipsius and Bacon, then, "fame" represented a clear example of the mutual implication of imagination and belief. In the essay on vainglory, Bacon pointed out that fame has the power to create reality out of nothing, "for Lies are sufficient to breed Opinion, and Opinion brings on Substance" (OFB XV, p. 161). Here Bacon referred to the episode of Mucianus in Tacitus' Historiae (II, 80), an episode that is mentioned twice in the Essayes (in the essay on simulation and dissimulation and in the fragment on fame). Bacon distinguished between two means of producing "Somewhat" out of "Nothing"; or, in other words, between purely ostentatious and deluded inventions, on the one hand, and a subtle art of discretion, on the other. Mucianus in Tacitus represented precisely this form of "Naturall Magnanimity," "not onely Comely, but Gracious" (to use Bacon's words), because, as Tacitus wrote, Mucianus "knew how to give a certain air to all he said and did" ("omniumque quae diceret atque ageret arte quadam ostentator") (Tacitus 1925, pp. 288-9; OFB XV, pp. 225, $365,388) .{ }^{14}$ In his unfinished essay on fame, Bacon characterized the analysis of this notion as one of the most important "in all the Politiques" (OFB XV, p. 177). He referred to the poetic description of fame as a monster, but he also acknowledged that such descriptions were "infected, with the stile of the Poets." This is an intriguing remark, all the more so because Savile, as we will see below, had used almost the exact same sentence to describe Tacitus' style ("infected with that heresie of the stile begun by Seneca, Quintilian, the Plinies, and Tacitus," as he wrote at the end of his translation of the Agricola) (Savile 1598, pp. 205-6).

Regardless of whether or not the emblematic description of fame as a monster was overly affected, Tacitus, Lipsius, and Bacon were all convinced that the mechanism of public perception and belief, fostered by rumors and reputation, was an extremely delicate matter, to be handled with care and intelligence. In the Advancement of Learning, Bacon called the perilous proximity of fiction and belief "facilitie of credite," and further distinguished between two forms of "accepting or admitting thinges weakely authorised or warranted": namely, a "beleefe of Historie" (also called, in le-

14. See Pomeroy 2006. 
gal language, "matter of fact") and "a matter of art and opinion" (OFB IV, p. 171). "Facilitie of credite" was responsible, in Bacon's view, for all sorts of fictional productions, from matters of religious faith to poetical inventions. It is worth remembering that the works in which he outlined the general framework of his philosophy-The Advancement of Learning and its later, expanded Latin version, De dignitate et augmentis scientiarum-rested on a threefold division of the faculties of human knowledge (memory, imagination and reason), and that by imagination Bacon understood the faculty, mentioned above, of "poesy," that is, "fained history." It is also worth pointing out that in the Latin version Bacon used the term phantasia and not imaginatio. This means that poesy and fained bistory are the products of a scarcely controllable tendency to represent reality, and neither derive from imaginatio, a real force of nature embedded in matter (OFB IV, p. 73). ${ }^{15}$

In a letter of advice to Henry Savile, in all likelihood written before the Advancement of Learning, Bacon explained that "fantastical learning"- the distemper of knowledge originating from the two basic tendencies discussed above (that is, disposition to deceive and willingness to be deceived) - rested on the pliant nature of the human mind. One of Bacon's most characteristic and recurrent arguments concerning human nature is that matter is supple and responsive: man, who is the most elaborate product of matter, is also the most pliant and responsive substance in nature. In fact, "Of all living and breathing substances," Bacon wrote in this letter, "the perfectest (Man) is the most susceptible of help, improvement, impression, and alteration. And not only in his body, but in his mind and spirit. And there again not only in his appetite and affection, but in his power of wit and reason" (Bacon 1996, p. 115). He pointed to "impostors and counterfeits" who are able "to wreath and cast their bodies in strange forms and motions," as well as to other people who can "bring themselves into trances and astonishments." For Bacon, all these examples demonstrated "how variously, and to how high points and degrees, the body of man may be (as it were) moulded and wrought." On the other hand, he recognized that such feats of human changeability remained confined to situations surrounded by diffidence and mistrust, as had been summed up in Virgil's words Possunt quia posse videntur, "They can because they think they can" (Aeneid, V, 231). The crux of the matter, argued Bacon, was that "no man shall know how much may be done, except he believe much may

15. See also De dignitate et augmentis scientiarum, in Works, 1:494: "Per Poësim autem hoc loco intelligimus non aliud quam historiam confictam, sive fabulas. Carmen enim stili quidam character est, atque ad artificia orationis pertinet." On the meanings of imaginatio and phantasia in Bacon, see Giglioni 2010. 
be done," where the emphasis was, once again, on the power of belief (Bacon 1996, p. 116).

In the same letter to Savile, Bacon claimed that of all the human faculties, corporeal and incorporeal, the will was the most "maniable and obedient," capable of being cured and altered by a whole range of "medicines." The most effective of such medicines ("the most sovereign of all"), Bacon continued, is religion, which is able to change and transform the will "in the deepest and most inward inclinations and motions." In addition to religious faith, Bacon mentioned five [the list includes five] other "medicines" to cure and alter the will: opinion, apprehension, example, affection, and custom (or habit). ${ }^{16}$ Bacon explained that the will's responsiveness to such "remedies" enabled it to "incline" (that is, direct) "affection and appetite," which he described as "inceptions and rudiments of will." The medicines of the will could result either in a "just or true cure" or in "palliation," that is to say, "either the labour and intention is to reform the affections really and truly, restraining them if they be too violent, and raising them if they be too soft and weak, or else is to cover them; or if occasion be, to pretend and represent them" (Bacon 1996, p. 117). The alternative presented by Bacon between the therapy of reforming the passions and the practice of covering and representing them attests to his own wavering opinion as to the efficacy of a Senecan versus a Tacitean treatment of the symptoms. A case in point is the syndrome of anger. In the essay dedicated to its analysis, Bacon argues that among the causes that lead to bouts of anger is "the Apprehension and Construction, of the Iniury offred, to be, in the Circumstances thereof, full of Contempt" (OFB XV). ${ }^{17}$ Likewise, to assess the nature and the circumstances of the offence in the correct way is the best remedy for avoiding anger; it is "to make a Mans Selfe

16. Bacon 1996, p. 117: "And next to that [i.e., religion] is opinion and apprehension; whether it be infused by tradition and institution, or wrought in by disputation and persuasion. And the third is example, which transformeth the will of man into the similitude of that which is more obversant and familiar towards it. And the fourth is, when one affection is healed and corrected by another; as when cowardice is remedied by shame and dishonour, or sluggishness and backwardness by indignation and emulation; and so the like. And lastly, when all these means, or any of them, have new framed or formed human will, then doth custom and habit corroborate and confirm all the rest."

17. Here Bacon's analysis of anger follows Seneca's view of the passion as a deluded reaction to reality due to frustration and resentment. Bacon's account is very similar to the one set out by the physician Johann Weyer in his De ira morbo, published in 1577: "Tertiam ponimus caussam irae internam, vitium instrumentorum quae sensui inserviunt. Nam quum natura et ad animae perfectionem et corporis commoditatem, sensus in nobis crearit, quibus obiecta phantasmata aut bona aut mala per antilepsin ad intellectum deducuntur: indignamur, quando nobis aliquid accidit quod erat fugiendum, et eo privamur quod fuerat percipiendum: quoniam tunc obrepit injuriae ab aliis illatae opinio, propterea quod destituti sensoriorum ministerio, citius falli queamus" (Weyer 1660, p. 784). 
beleeue, that the Opportunity of his Reuenge is not yet come" (OFB XV, pp. 170-1). The treatment of anger shows that the complex cycle of delusion and self-delusion is subtly at work each and every time we are in the grip of a passion: on the one hand, a Senecan awareness that our pathos results from an ill-perceived logos may lead to the eradication of the cause of our distress (that is, an anticipated apprehension); on the other, a Tacitean control of our tendency "to make ourselves believe" that things exist a certain way can provide a necessary palliative to emotional imbalance in the middle of a sudden bout of anger.

Bacon associated the two strategies for altering the human will-the "true cure" and the "palliation" — with, respectively, moral philosophy and various forms of behavior displayed in princely courts and situations of "politic traffic," where, he says:

it is ordinary to find not only profound dissimulations and suffocating the affections that no note or mark appear of them outwardly, but also lively simulations and affectations, carrying the tokens of passions which are not, as "risus jussus" and "lachrymae coactae", and the like. (Bacon 1996, p. 117)

Bacon "played the courtier with Tacitus' assistance," Mary Tenney once wrote in her essay on the use of Tacitus in Stuart politics (Tenney 1941, p. 155). No doubt, to be at court was like being an actor in a drama. And in this instance, too, Tacitus could come in handy. In the Advancement of Learning, Bacon referred to a "notable example in Tacitus of two stageplayers, Percennius and Vibulenus, who by their faculty of playing put the Pannonian armies into an extreme tumult and combustion" (OFB IV, p. 132). In De diginitate et augmentis scientiarium, the story taken from Tacitus' Annales (I, 16-22) was rewritten in an expanded version, and inserted into a section in which Bacon praised the Jesuits' ability to use plays as teaching tools. In an appendix devoted to the "critical" and "pedagogical" sections of the "art of transmission," he recommended following "the schools of the Jesuits," for "nothing better has been put in practice":

even mean faculties, when they fall into great men or great matters, sometimes work great and important effects. Of this I will adduce a memorable example; the rather, because the Jesuits appear not to despise this kind of discipline; therein judging (as I think) well. It is a thing indeed, if practised professionally, of low repute; but if it be made a part of discipline, it is of excellent use. I mean stageplaying: an art which strengthens the memory, regulates the tone and effect the voice and pronunciation, teaches a decent carriage of 
the countenance and gesture, gives not a little assurance, and accustoms young men to bear being looked at.

Then Bacon once more recounted the episode of Vibulenus, "formerly an actor, then a soldier in the Pannonian legions," who convinced his audience-the army, in this case- that his brother had been killed by Blaesus, when, in fact, he had no brother at all. Bacon concluded that "the fact was that he played the whole thing as if it had been a piece on the stage" (SEH I, p. 711; IV, pp. 496-7). ${ }^{18}$ This is another situation in which Bacon showed that Tacitus' Historiae and Annales could be used as repositories of examples, illustrating not so much the inflexible rigor of virtue as the inherently pliable character of human nature (both body and mind) in a large number of situations, such as the spread of fame and public reputation, the interplay of matters of fact and of opinion, the porous boundaries between the theatre and the court, and the realms of fabricated reality (fictum) and credulity (creditum). As has already been noted, Bacon had addressed the question of the extent to which human nature could be "moulded and wrought" by all sorts of helps and "medicines" in his letter of advice to Savile. One may wonder whether Bacon was somehow influenced by the way Savile had presented Tacitus' works to English readers in his translations of the Agricola and Historiae. After all, both Savile and Bacon were influential members of the cultural milieu of their age and, crucially, shared important friendships and connections. As we shall see in the next section, though, Savile and Bacon had quite different views about Tacitus and the possible uses of his historical analysis.

\section{Henry Savile on Tacitus}

Henry Savile, the addressee of Bacon's letter, played a central role in the history of the English reception of Tacitus through his translation of both the Agricola and the first four books of the Historiae in 1591 (reprinted five times, in 1598, 1604, 1612, 1622, and 1640). The rest of Tacitus' historical works-the Germania and Annales - were translated by Richard Greneway in 1598. To his translation of Tacitus' Historiae, Savile added a book of his own-The Ende of Nero and Beginning of Galba —written to bridge the gap between the Annales and the Historiae (from AD 68 to 1 January 69). Savile's treatise is an intriguing combination of history and imagination, a representation of historical events through the medium of "poesy," to use Bacon's own technical term.

Born in 1549, Savile studied in Oxford and travelled extensively on the Continent for several years between 1578 and 1582, before being ap-

18. See Vickers 1990 for Bacon's use of theatrical imagery. 
pointed Warden at Merton College in 1585 and Provost of Eton College in 1595 (Goulding 2004). Lipsius knew and appreciated Savile (Etter 1966 , p. 133). Womersley has meticulously traced the changes and interpolations added by Savile to the traditional sources available to him at the time, such as the key encomium of Julius Vindex, the principal force behind the anti-Neronian conspiracy (Womersley 1991, p. 318). In his opinion, Savile's positive characterization of the rebellion against Nero was an indirect way of supporting Essex's "military self-fashioning" (Womersley 1991, p. 314). Womersley is not the first to connect Savile to the Earl of Essex and his circle (Savile was indeed temporarily arrested in 1601 after the failure of Essex's coup): the Essex circle has been described by historians as a coterie imbued with ideas coming from Tacitus and Machiavelli. One piece of evidence is the role played by Henry Cuffe, who became secretary to Essex in 1594 and was helped by Savile when he was studying at Merton College. Essex, in turn, supported Savile's application for the Prevostship of Eton (Womersley 1991, p. 316).

In The Ende of Nero and Beginning of Galba, Savile, relying on the extant works of Tacitus, Suetonius, Cassius Dio, and Plutarch's "Life of Galba," managed to weave together all the various strands of available information into a coherent narrative concerning the two most crucial years of Nero's life. Very appropriately, Womersley quotes a passage on the writing of history from the Advancement of Learning: "he that vndertaketh the story of a time, especially of any length," Bacon explained, "cannot but meet with many blankes and spaces, which hee must be forced to fill vp out of his own wit and coniecture" (Womersley 1991, pp. 315-6; OFB IV, p. 66). In this instance, the "blankes" and "spaces" were filled with a distinctive view of political virtue. Womersley argues that, by depicting the attempted rebellion against Nero as an act of virtue and courage, Savile was, in fact, defending the right to resist divinely ordained monarchies if and when they turned into tyrannical regimes. In this sense, Savile's translation supported "Essex's political strategy in the early 1590s" (Womersley 1991, p. 317). To strengthen his case, Womersley adds that Savile had been influenced by continental Huguenot thought, and that, like Huguenot political thinkers, he used Machiavelli's Principe in an anti-tyrannical sense, the same use found in such texts as François Hotman's Franco-Gallia (1573) and Vindiciae contra tyrannos (the anonymous Huguenot treatise published in Basel in 1579), for example (Womersley 1991, p. 330).

It is true that, in The Ende of Nero and Beginning of Galba, Savile presents Nero as a ruler who failed because his virtue was not strong enough to resist the enormity of his vices. Nevertheless, to interpret the discrepancy between Nero's virtue and his appetites according to Machiavelli (namely, seeing virtue as a powerful and vital resource indispensable for preserving 
the state) or even in a sort of Nietzschean sense, as "creative, amoral energy" (Womersley's words), is to read too much into the text. As I noted at the beginning of this essay, at the turn of the seventeenth century, Tacitus' writings could be used in many different ways, ranging from a justification of tyranny to advocating armed resistance to tyranny. And yet, it can be said that Savile's translations belies his own distinctive, hermeneutical agenda. Apparently, he was neither especially fond of indulging in overwrought readings of Tacitean loci (explaining obscura per obscuriora), nor did he intend to flesh out Stoic virtue through elements of Tacitean realism. As Edwin B. Benjamin has observed in his article on Bacon and Tacitus, Savile was not very impressed by Tacitus' style (Benjamin 1965, p. 110b). This is clearly evident in a note Savile added to his translation of the Agricola, in which he expressed strong reservations-by no means confined to the obscurity of his style-about Tacitus' writing. The note can be found at the end of his volume of Tacitean translations, as if he felt the need to vent a certain level of uneasiness (indeed, frustration) concerning the style of the author he had just finished translating. It is, in a way, a strange coda, very different from the anonymous preface at the beginning of the book which is full of positive remarks about Tacitus and his gnomic use of history. Savile's note contains a series of valuable comments, and is worth quoting in full, for it also sheds light on the interplay of fingere and credere:

A good man you would easily thinke him: \&c. Bonum virum facile crederes, magnum libenter. $]^{19}$ Et te Corneli Tacite bonum historicum facile credimus, bonum oratorem crederemus libenter, were it not for this and some other sayings of the like making. Fuit illo viro, saieth Tacitus iudging of Seneca, as we may of him, ingenium amoenum, et temporis illius auribus accommodatum. ${ }^{20}$ How that age was eared, long or round, I cannot define: but sure I am it yeelded a kinde of Sophisticate eloquence, and riming harmony of wordes, whereunder was small matter in sense, when there seemed to be most in apparence. This kinde of Rhetoricke was induced into Graecia by the teachers of oratories in schoole, whose iudgements use and experience had not refined: first by Gorgias, as it may well appeare by that little of his which is left; then by Isocrates and his disciples, and being refused by that iudicious nation found favour in some corners of Asia, til at length the use of eloquence decaying in common wealth, and the study thereof remaining in schooles, that bastard Rhetoricke returned againe, yeelding us in steede of

19. Tacitus, Agricola, 44.

20. Tacitus, Annales, XIII, 3. 
the soundly contrived sentences of Demosthenes, AEschines, Hyperides, the paintings of Aristidis, ${ }^{21}$ Philostratus, Dio Chrysostomus, and others, though not without opposition of many, as Dionysius, Lucian and such like. The auncient Romans sucking the best from the Greekes, when they were at their best fayled not much that way, unlesse peradventure wee may recken Hortensius as one of the number: for so Tully in Bruto seems to describe him. ${ }^{22}$ But of the later, whom have wee almost not infected with that heresie of the stile begun by Seneca, Quintilian, the Plinies, and Tacitus, continued in their successours the Panegyrists, and lastly conveyed to Christian religion by Cyprian, Ambrose, Augustin, Bernard, \&c? (Savile 1598, pp. 205-6)

Taking his cue from one of Tacitus' classic, sententious statements-bonum virum facile crederes, magnum libenter, "a good man you would easily thinke him, and willingly a great," to use his own translation-Savile goes so far as to question Tacitus' good faith and sincerity. What he is claiming, is that, while it is not hard to appreciate Tacitus as a good historian, his underlying rhetorical strategy cannot be trusted. The problem Savile seems to have with Tacitus is the divide between historical and rhetorical truth, between "sense" and "apparence," such that his cunning use of rhetorical devices ("sophisticate eloquence") casts a shadow over the historical narrative. In doing so, Tacitus' way of writing recreates in the mind of the reader the same mechanism of self-delusion (fingunt creduntque) he so eloquently represents at work in the domain of history (Savile 1598, p. 205). As a result, where for Bacon it is precisely the combination of rhetorical awareness and empirical investigation that makes Tacitus' history a powerful instrument of philosophical analysis, for Savile, Tacitus' comments and subjective intrusions are inappropriate and corrupting interventions in an account of events that should ideally remain as objective as possible.

Judging from what Savile writes in this dense note, he is undoubtedly questioning Tacitus' reliability as a historian. Should we believe him? In quite a witty fashion, he paraphrases one of Tacitus' famous maxims in order to compose a maxim of his own. As in Tacitus' case, the crux of the matter is the nature of credere and fingere, belief and representation. Savile addresses Tacitus in a direct manner: "Et te Corneli Tacite ...": "You, too, Cornelius Tacitus, we easily think you are a good historian, and willingly

21. Pliny, Historia naturalis, XXXV, 98: "Is [Aristides Thebanus] primus animum pinxit et sensus hominis expressit, quae vocant Graci $\backslash 2,212 \backslash \backslash \theta \eta$, item perturbationes, durior paulo in coloribus."

22. Cicero, Brutus, XCV, 325: "genus erat orationis Asiaticum adulescentiae magis concessum quam senectuti." 
would think that you are a good orator." Tacitus' crederes in the Agricola is a potential subjunctive, second person singular used in an impersonal sense; Savile's crederemus is a conditional subjunctive, first person plural, required by the protasis "were it not." In this context, the difference between potentiality and unreality in the use of the subjunctive is not a minor one.

Savile also adds a reference to Tacitus' Annales (XIII, 3): the famous locus where Tacitus describes Seneca. In Savile's annotation, the figures of Seneca and Tacitus seem almost to coalesce into symbols of pleasing brilliance (amoenum ingenium), suitable for only a shallow and jaded audience. For Savile, it is a form of "sophisticate eloquence," originating with Gorgias, culminating in the "heresie of the stile begun by Seneca, Quintilian, the Plinies, and Tacitus," and resumed by Christians such as "Cyprian, Ambrose, Augustin, Bernard." It is an "affectation" that has a corrupting influence on contemporary style. Savile's annotation on Tacitus' maxim in the Agricola thus expands into a short and pithy history of rhetoric from Gorgias to the Church Fathers. What is more, Savile argues that the ancient rhetoric of the Greeks introduced a baleful opposition between meaning ("sense") and appearance. Tacitus, in Savile's opinion, indulged in this rhetorical opposition between appearance and reality. The examples of Tacitean writing that Savile provides at the end of the note are meant to be a concrete illustration of the effects caused by this "bastard Rhetoricke." The severe critique of Tacitus' style at the end of the volume perhaps explains why, in the anonymous preface at the beginning, the translation is presented as a remedy for people with a delicate stomach, those who cannot "digest Tacitus in his owne stile." Savile, it continues, "giues

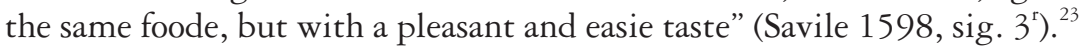

\section{Conclusion}

Since, from a metaphysical point of view, Bacon thinks that the ultimate reality of things lies in their material cupidity - a kind of cupidity that, despite Stoic claims to the contrary, cannot be eradicated by forms of rational volition-the perception that human beings have of their own reality is unavoidably distorted by varying degrees of delusion. Life is first of all a matter of reacting, more or less acutely, to stimuli and provocations. In this sense, the function of appetite is more original than that of perception and knowledge. ${ }^{24}$ Given that our cognitive powers are feeble and can easily be overcome by the power of desire, Bacon's appetites become

23. In this context, see also the very interesting remark by Bacon in Historia vitae et mortis: "Rhetores, qui Res degustabant tantum, et potius Orationis Lumen, quam Rerum Obscuritatem sectabantur, fuerunt itidem Longaevi (ut Gorgias, Protagoras, Isocrates, Seneca)."

24. On Bacon's metaphysics of appetite, see Giglioni 2011a. 
caught up in a murky interplay of fingere and credere, such that perception inevitably becomes opaque. In this sense, Tacitean intertwinings of imagination (fingere) and belief (credere) form the very fabric of Bacon's idola. What this means, is that a Tacitean view of reality-one in which the transparency and reliability of representations are constantly questionedis well suited to an inherently political view of nature as advocated by Bacon, in which perceptions can never escape the grip of material appetites. Bacon thought that Tacitus' history contained a general inquiry into the very roots of human delusion. For this reason, Tacitus could be said to be a better philosopher than Plato and Aristotle. He was, without a doubt, better than Seneca, who, in Bacon's opinion, often mistook philosophy for "poesy," that is, a fictional account of things better suited for peeking into the "transcendencies" of human life.

By contrast, Savile held a very different opinion of Tacitus' history. Far from praising Tacitus in order to smuggle heroic views of virtue and freedom (in line with the political agenda of the Essex circle) into the contemporary debate (as has been suggested by Womersley), Savile saw in Tacitus an insidious and contagious use of rhetorical deception: he emphasized the moment of intentionality in the process of deception, which he referred to as the "infection" of stylistic heresy. In fact, there is a markedly ethical preoccupation in the way he addressed Tacitus and his writing of history; a preoccupation that one searches for in vain in Bacon, for whom intentions (both in the domain of nature and human society) were too clouded to play a viable role in any explanation of both natural and historical events.

\section{References}

Abel, Günter. 1978. Stoizismus und frühe Nenzeit: Zur Entstehungsgeschichte modernen Denkens im Felde von Ethik und Politik. Berlin: De Gruyter.

Bacon, Francis. 1985- . The Oxford Francis Bacon (OFB). Edited by Graham Rees and Brian Vickers. Oxford: Clarendon Press.

Bacon, Francis. 1857-1874. The Works of Francis Bacon (SEH). Edited by James Spedding, Robert Leslie Ellis, and Douglas Denon Heath. 14 vols. London: Longmans and Co.

Bacon, Francis. 1996. The Major Works. Edited by Brian Vickers. Oxford: Oxford University Press.

Bacon, Francis. 2009. Récusation des doctrines philosophiques et autres opuscules. Edited by Didier Deleule. Paris: Hermann.

Benjamin, Edwin B. 1965. "Bacon and Tacitus." Classical Philology 60: 102-10.

Bradford, Alan T. 1983. "Stuart Absolutism and the 'Utility' of Tacitus." Huntington Library Quarterly 46: 127-55. 
Brink, C. O. 1951. "Justus Lipsius and the Text of Tacitus." The Journal of Roman Studies 41: 32-51.

Burke, Peter. 1969. "Tacitism." Pp. 149-71 in Tacitus. Edited by Thomas Alan Dorey. London: Routledge \& Kegan Paul.

Burke, Peter. 1991. "Tacitism, Scepticism, and Reason of State." Pp. 479_ 98 in The Cambridge History of Political Thought 1450-1700. Edited by James Henderson Burns with the assistance of Mark Goldie. Cambridge: Cambridge University Press.

Carabin, Denise. 2004. Les idées stö̈ciennes dans la littérature morale des XVI et XVII siècles (1575-1642). Paris: Honoré Champion.

Croll, Morris W. Style, Rhetoric and Rhythm. Edited by J. Max Patrick and R. O. Evans, with J. M. Wallace and R. J. Schoeck. Princeton: Princeton University Press.

Dal Pra, Mario. 1946. "Note di storia della storiografia filosofica I: Giusto Lipsio." Rivista di Storia della Filosofia 1: 163-88.

Deleule, Didier. 2009. "Introduction." Pp. 5-45 in F. Bacon, Récusation des doctrines philosophiques et autres opuscules. Edited by Didier Deleule. Paris: Hermann.

Etter, Else-Lilly. 1966. Tacitus in der Geistesgeschichte des 16. und 17. Jabrbunderts. Basel: Helbing \& Lichtenhahn.

Ferraro Parmelee, Lisa. 1994. "Neostoicism and Absolutism in Late Elizabethan England." Pp. 3-19 in Politics, Ideology and the Law in Early Modern Europe. Edited by Adrianna E. Bakos. Rochester, NY: University of Rochester Press.

Haynes, Holly. 2003. Tacitus on Imperial Rome: The History of Make-Believe. Berkeley, Los Angeles and London: University of California Press.

Gajda Alexandra. 2009. "Tacitus and Political Thought in Early Modern Europe, c. 1530-c. 1640.” Pp. 253-68 in The Cambridge Companion to Tacitus. Edited by Anthony John Woodman. Cambridge: Cambridge University Press.

Giglioni, Guido. 2010. "Fantasy Islands: Utopia, The Tempest and New Atlantis as Places of Controlled Credulousness." Pp. 90-117 in WorldBuilding and the Early Modern Imagination. Edited by Allison B. Kavey. New York: Palgrave Macmillan.

Giglioni, Guido. 2011a. Francesco Bacone. Rome: Carocci.

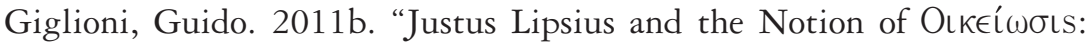
A Note on the Early-Modern Notion of Self-Preservation.” Pp. 32-51 in Justus Lipsius and Natural Philosophy. Edited by Hiro Hirai and Jan Papy. Brussels: Royal Academy of Belgium.

Goulding, Robert D. 2004. "Sir Henry Savile." Oxford Dictionary of $\mathrm{Na}$ tional Biography, 60 vols. Edited by H. C. G. Matthew and Brian Harrison. Oxford: Oxford University Press 49: 109-18. 
Grafton, Anthony. 1987. "Portrait of Justus Lipsius." American Scholar 56: 382-90.

Harrison, Peter. 2007. The Fall of Man and the Foundations of Science. Cambridge: Cambridge University Press.

Isnardi Parente, Margherita. 1986. "La storia della filosofia antica nella Manuductio in Stoicam philosophiam di Giusto Lipsio." Annali della Scuola Normale Superiore di Pisa 16: 45-64.

Joly, Bernard. 1996. "Mundum animal esse (Physiologia Stoicorum II, 10): Retour au stoïcisme ou triomphe de l'hermétisme?” Pp. 49-69 in Juste Lipse (1547-1606) en son temp. Edited by Christian Mouchel. Paris: Honoré Champion.

Kelley, Donald, R. 1993. "Tacitus Noster: The Germania in the Renaissance and Reformation." Pp. 152-67 in Tacitus and the Tacitean Tradition. Edited by Torrey James Luce and Anthony John Woodman. Princeton: Princeton University Press.

Kraye, Jill. 2004. "Stoicism in the Renaissance from Petrarch to Lipsius." Pp. 21-45 in Hugo Grotius and the Stoa. Edited by Hans W. Blom and Laurens C. Winkel. Assen, NL: Royal Van Gorcum.

Lagrée, Jacqueline. 1994. Juste Lipse et la restauration du stoïcisme. Paris: Vrin.

Lagrée, Jaqueline. 1996. "Juste Lipse: théorie des principes et théologie naturelle." Pp. 31-47 in Juste Lipse (1547-1606) en son temps. Edited by Christian Mouchel. Paris: Honoré Champion.

Lagrée, Jacqueline. 1999. “Juste Lipse: l'âme et la vertu." Pp. 90-106 in Iustus Lipsius Europae Lumen et Columen. Edited by Gilbert Tournoy, Jeanine Landtsheer and Jan Papy. Leuven: Leuven University Press.

Lagrée, Jacqueline. 2010. Le néostö̈cisme. Paris: Vrin.

La Penna, Antonio. 1976. "Vivere sotto i tiranni: Un tema tacitiano da Guicciardini a Diderot.” Pp. 295-303 in Classical Influences on European Culture 1500-1700. Edited by R. R. Bolgar. Cambridge: Cambridge University Press.

Leira, Halvard. 2007. "At the Crossroads: Justus Lipsius and the Early Modern Development of International Law." Leiden Journal of International Law 20: 65-88.

Leira, Halvard. 2008. "Justus Lipsius, Political Humanism and the Disciplining of 17th Century Statecraft." Review of International Studies 34: 669-92.

Lipsius, Justus. 1675. Opera omnia, 4 vols. Wesel: André van Hoogenhuysen.

Lipsius, Justus. 2004. Politica. Edited by Jan Waszink. Assen, NL: Royal Van Gorcum.

Long, Anthony. A. 2003. "Stoicism in the Philosophical Tradition: Spin- 
oza, Lipsius, Butler." Pp. 365-92 in The Cambridge Companion to the Stoics. Edited by Brad Inwood. Cambridge: Cambridge University Press.

Martin, R. H. 2009. "From Manuscript to Print." Pp. 241-52 in The Cambridge Companion to Tacitus. Edited by Anthony John Woodman. Cambridge: Cambridge University Press.

Mellor, Ronald. 1993. Tacitus. New York and London: Routledge.

Miner, Earl. 1970. "Patterns of Stoicism in Thought and Prose Style, 1530-1700." Publications of the Modern Language Association 85: 102334.

Momigliano, Arnaldo. 1947. "The First Political Commentary on Tacitus." Journal of Roman Studies 37: 91-101 (repr. in Contributi alla storia degli studi classici, 9 vols., Rome: Edizioni di Storia e Letteratura, 1955-1980, I, pp. 38-59).

Morford, Mark. 1991. Stoics and Neostoics: Rubens and the Circle of Lipsius. Princeton: Princeton University Press.

Morford, Mark. 1993. Pp. 129-51 in Tacitus and the Tacitean Tradition. Edited by Torrey James Luce and Anthony John Woodman. Princeton: Princeton University Press.

Norbrook, David. 2002. Poetry and Politics in the English Renaissance. Oxford: Oxford University Press.

Nordman Viljo Adolf. 1932. Justus Lipsius als Geschichtsforscher und Geschichtslebrer: Eine Untersuchung. Helsinki: Annales Academiae Scientiarum Fennicae.

Oestreich, Gerhard. 1982. Neostoicism and the Early Modern State. Cambridge: Cambridge University Press.

Paganini, Gianni. 2000. "Giusto Lipsio e la rinascita della fisica stoica." Pp. 81-98 in La geografia dei saperi: Scritti in memoria di Dino Pastine. Edited by Domenico Ferraro and Gianna Gigliotti. Florence: Le Lettere.

Papy, Jan. 2004. "Lipsius's (Neo-)Stoicism: Constancy between Christian Faith and Stoic Virtue." Pp. 47-71 in Hugo Grotius and the Stoa. Edited by Hans W. Blom and Laurens C. Winkel. Assen, NL: Royal Van Gorcum.

Papy, Jan. 2008. "Le sénéquisme dans la correspondance de Juste Lipse. Du De constantia (1583) à la Epistolarum selectarum centuria prima miscellanea (1586)." Journal de la Renaissance 6: 49-62.

Pomeroy, Arthur John. 2006. "Theatricality in Tacitus's Histories." Arethusa 39: 171-91.

Ramorino, Felice. 1898. Cornelio Tacito nella storia della coltura. Milan: Hoepli. 
Ruysschaert, José. 1949. Juste Lipse et les Annales de Tacite. Une méthode de critique textuelle au XVI siècle. Louvain: Bibliothèque de l'Université.

Sailor, Dylan. 2008. Writing and Empire in Tacitus. Cambridge: Cambridge University Press.

Salmon, J. H. M. 1980. "Cicero and Tacitus in Sixteenth-Century France." The American Historical Review 85: 307-31 (repr. in J. H. M. Salmon, Renaissance and Revolt: Essays in the Intellectual and Social History of Early Modern France. Cambridge: Cambridge University Press, 1987, pp. 2753).

Salmon, J. H. M. 1989. "Stoicism and Roman Example: Seneca and Tacitus in Jacobean England." Journal of the History of Ideas 50: 199225 (repr. in The Mental World of the Jacobean Court. Edited by Linda Levy Peck. Cambridge: Cambridge University Press, 1991, pp. 16988).

Saunders, Jason Lewis. 1955. Justus Lipsius: The Philosophy of Renaissance Stoicism. New York: Liberal Arts.

Savile, Henry. 1598. The Ende of Nero and Beginning of Galba. Fower Bokkes of the Histories of Cornelius Tacitus. The Life of Agricola. London: Arnold Hatfield.

Schellhase, Kenneth C. 1976. Tacitus in Renaissance Thought. Chicago and London: The University of Chicago Press.

Senellart, Michel. 1999. "Le stoïcisme dans la constitution de la pensée politique: Les Politiques de Juste Lipse (1589).” Pp. 117-39 in Le stö̈cisme au XVI et au XVII siècle: Le retour des philosophies antiques à l'Âge classique. Edited by Pierre-François Moreau. Paris: Albin Michel.

Smith, Philip A. 1948. "Bishop Hall, 'Our English Seneca'." Publications of the Modern Language Association 63: 1191-1204.

Tacitus, 1574. Historiarum et Annalium libri qui extant. Edited by Justus Lipsius. Antwerp: Christophe Plantin.

Tenney, Mary. F. 1941. "Tacitus in the Politics of Early Stuart England." The Classical Journal 37: 151-63.

Toffanin, Giuseppe. 1921. Machiavelli e il tacitismo. Padua: Draghi.

Tuck, Richard. 1993. Philosophy and Government 1572-1651. Cambridge: Cambridge University Press.

Vickers, Brian. 1971. "Bacon's Use of Theatrical Imagery." Pp. 171-213 in Francis Bacon's Legacy of Texts. Edited by William A. Sessions. New York: AMS Press.

Weyer, Johann. 1660. De ira morbo, eiusdem curatione philosopbica, medica et theologica liber, in his Opera omnia. Amsterdam: Peter vanden Berge.

Whitfield, J. H., "Livy > Tacitus." Pp. 281-93 in Classical Influences on European Culture A.D. 1500-1700. Edited by R. R. Bolgar. Cambridge: Cambridge University Press. 
Williamson, George. 1951. The Senecan Amble: A Study in Prose from Bacon to Collier. London: Faber.

Womersley, David. 1991. "Sir Henry Savile's Translation of Tacitus and the Political Interpretation of Elizabethan Texts." The Review of English Studies 42: 313-42.

Womersley, David. 1992. "Sir John Hayward's Tacitism." Renaissance Studies 6: 46-59.

Zanta, Léontine. 1914. La renaissance du stö̈cisme au XVI siècle. Paris: Champion. 